\title{
Female reproductive tract pain: targets, challenges, and outcomes
}

\author{
Phillip Jobling*, Kate O'Hara and Susan Hua \\ School of Biomedical Sciences and Pharmacy, The University of Newcastle, Callaghan, NSW, Australia
}

Edited by:

Peter John Cabot, The University of Queensland, Australia

\section{Reviewed by:}

Ciaran J. Faherty, Cadence

Pharmaceuticals, USA

Leighann Litcher-Kelly, Stony Brook

University, USA

\section{*Correspondence:}

Phillip Jobling, School of Biomedical

Sciences and Pharmacy, The

University of Newcastle, Callaghan,

NSW 2038, Australia

e-mail:phillip.jobling@

newcastle.edu.au
Pain from the female reproductive tract (FRT) is a significant clinical problem for which there are few effective therapies. The complex neuroanatomy of pelvic organs not only makes diagnosis of pelvic pain disorders difficult but represents a challenge to development of targeted therapies. A number of potential therapeutic targets have been identified on sensory neurons supplying the FRT but our knowledge on the basic neurophysiology of these neurons is limited compared with other viscera. Until this is addressed we can only guess if the new experimental therapies proposed for somatic, gastrointestinal, or bladder pain will translate to the FRT. Once suitable therapeutic targets become clear, the next challenge is drug delivery. The FRT represents a promising system for topical drug delivery that could be tailored to act locally or systemically depending on formulation. Development of these therapies and their delivery systems will need to be done in concert with more robust in vivo and in vitro models of FRT pain.

Keywords: pelvic pain, vagina, cervix, uterus, drug delivery

\section{INTRODUCTION}

Pain syndromes represent one of the major challenges of neurology. Pain has many definitions but essentially it is a concept generated across the brain in response to internal or external stimuli that the individual associates with real or perceived tissue damage or imminent threat (Merskey and Bogduk, 1994). Pain is difficult enough to treat when it arises from a relatively straightforward injury to a defined region like a small piece of skin or a single joint. Pain from pelvic organs, particularly the reproductive tract, is notoriously difficult to treat. In this review we will examine the complex and unique innervation of the female reproductive tract (FRT), current treatments and the potential for topical therapies.

The prevalence of transient pelvic pain (usually dysmenorrhea) has been placed as high as $70-80 \%$ of women surveyed while chronic pelvic pain was reported at $>20 \%$ (Hillen et al., 1999; Pitts et al., 2008). Ten percent of outpatient gynecological visits are for intractable pelvic pain (Ryder, 1996), and pelvic pain is the primary reason for $12-18 \%$ of hysterectomies (Kramer and Reiter, 1997). United kingdom estimates from 2000 placed direct healthcare costs at $£ 158$ million (Stones et al., 2000) whereas 1996 data from the USA placed patients' out of pocket expenses at $\$ 1.9$ billion dollars and indirect costs due to time off work at over $\$ 500$ million (Mathias et al., 1996). Importantly many women do not seek treatment for their pain (Mathias et al., 1996).

Chronic pelvic pain is further divided into "specific diseaseassociated pelvic pain" and "chronic pelvic pain syndrome" where the underlying pathology remains obscure (International Association for the Study of Pain, 2011). Pelvic pain may arise from a number of structures, both somatic (e.g., striated pelvic floor muscles), and visceral (reproductive tract, bladder, and lower bowel). Focusing on reproductive structures, clinical observations have identified numerous predictors of chronic pelvic pain including endometriosis, pelvic inflammatory disease, childbirth, and urinogenital atrophy following menopause (Giamberardino, 2008; Lara et al., 2009; Paterson et al., 2009).

\section{THE COMPLEX NATURE OF PAIN FROM THE FRT}

Sexual behavior and reproduction rely on the integration of nervous and hormonal signals to a widely distributed collection of structures. The external genitalia are essentially somatic structures and the distribution of sensory axons and their neurochemical coding are similar to cutaneous tissues (Martin-Alguacil et al., 2008; Moszkowicz et al., 2011; Vilimas et al., 2011). Sensory neurons innervating the hollow organs show different patterns of neurochemical expression compared with those that supply somatic structures (skin, muscle, and joints; Cervero and Laird, 2004; Song et al., 2009) and marked differences in central axons termination in the spinal cord (Sugiura et al., 1989, 1993).

Pain arising from the vagina, cervix, and uterus is an example of visceral nociception - or pain that comes from distension, injury, or inflammation of hollow organs (Cervero and Laird, 1999). Visceral pain is diffuse, poorly localized, often referred to other body regions, and can be accompanied by disrupted motor and autonomic reflexes (Janig and Morrison, 1986; McMahon, 1997; Westlund, 2000).

\section{EXTERNAL GENITALIA}

The most widely reported pain syndromes associated with external genitalia are the vulvodynias (Petersen et al., 2008; Fugl-Meyer et al., 2012). These have a prevalence of around 10\% in U.S studies (Harlow and Stewart, 2003; Petersen et al., 2008). Most sensations from the external genitalia are transmitted via axons in the pudendal nerve (Martin-Alguacil et al., 2008; Moszkowicz et al., 2011; 


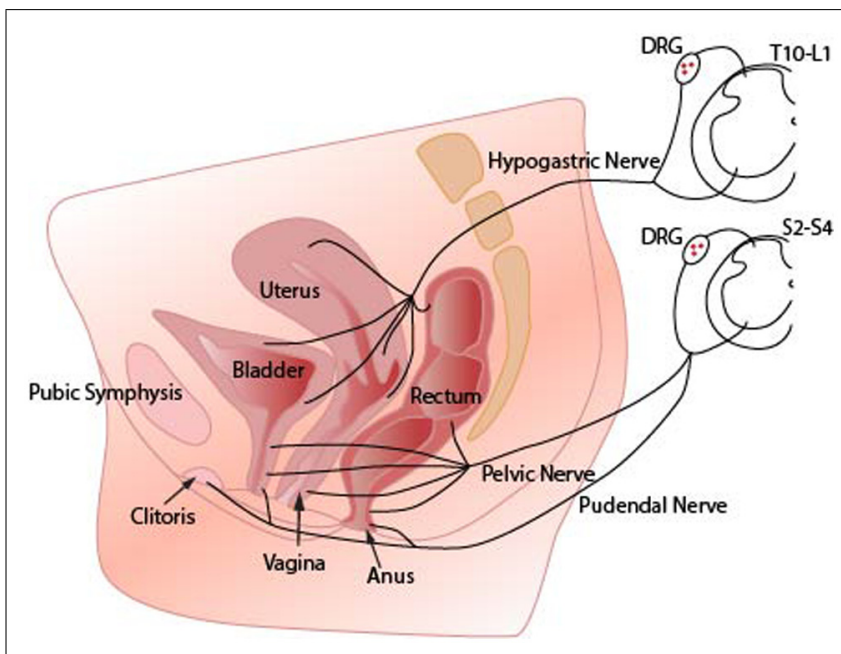

FIGURE 1 | Innervation of pelvic organs. Sensory axons innervating the vagina reach the spinal cord via pelvic nerves and terminate in sacral spinal cord segments (S2-S4). Axons innervating the uterus travel in the hypogastric nerves and terminate in the thoracolumbar spinal cord segments (T10-L2). The region surrounding the cervix represents a transitional zone and is innervated by fibers that travel in both nerves. Sensory axons from the clitoris and vulva follow the pudendal nerves to sacral spinal cord. Note that sensory information from all pelvic organs may converge onto the same spinal cord neural circuits. DRG (dorsal root ganglia).

Vilimas etal., 2011; Figure 1). Limited data indicate that often pain from these structures is similar to generalized somatic pain as opposed to visceral pain (Bachmann et al., 2006; Goldstein and Burrows, 2008).

\section{SENSATIONS FROM THE VAGINA, CERVIX AND UTERUS ENTER THE CNS AT MULTIPLE LEVELS}

The walls of the FRT are innervated with sensory afferent terminals that respond to both distension and inflammatory mediators (Berkley etal., 1993b; Papka and Traurig, 1993). The FRT is innervated via two main spinal nerve trunks; the hypogastric and pelvic nerves that send sensory information to a number of spinal cord segments (Figure 1; Berkley et al., 1993a,b; Wesselmann and Lai, 1997; Wesselmann, 2001; Jobling et al., 2003, 2010).

Electrical recordings from axons in rodents indicate that there is a heterogeneous distribution of receptors. Most axons respond to distension, whilst others respond to both distension and chemical stimuli (e.g., bradykinin or serotonin; Berkley et al., 1993a,b). Compared with the FRT, sensory axons supplying the gastrointestinal tract (GIT) and bladder have been better studied. Five functional classes of sensory axons have been described in the GIT (Page etal., 2002; Brierley etal., 2004; Song et al., 2009) and four functional classes of bladder sensory axons have been identified (Zagorodnyuk et al., 2007). There is an extensive interaction between vagina, cervix, uterus, and somatic structures (Hotta etal., 1999) where there is considerable convergence of these pathways in the spinal cord. The most widely and longrecognized consequence of this convergence is referred pain (Head, 1893).

\section{CENTRAL SENSITIZATION “PELVIC PAIN WITHOUT PELVIC ORGANS"}

A significant barrier to treatment is the observation that pelvic pain can exist in the absence of any obvious pathology. In fact pelvic pain is often resistant to the removal of the allegedly offending organs (Baskin and Tanagho, 1992). This observation is thought to be caused by the phenomenon of central sensitization. The mechanisms underlying central sensitization for somatic afferents have been examined in detail (Millan, 1999; Jones and Sorkin, 2003; Lu et al., 2009), however, central sensitization from FRT afferents remain poorly understood. Inflammation of the rat uterus increased receptive field size, and decreased thresholds for cervix afferents (Berkley et al., 1993a). Another study has shown that FRT inflammation recruits large numbers of neurons in the dorsal horn (Wesselmann et al., 2000).

\section{PELVIC ORGAN CROSSTALK - LINKING VAGINA, CERVIX, UTERUS BLADDER, AND BOWEL}

Epidemiological data suggest strong comorbidity between inflammatory bowel disorders, interstitial cystitis, and pelvic pain (Whorwell etal., 1986). Some of this comorbidity might be explained by the sensory and motor pathways that link FRT, bladder, and lower bowel (Winnard et al., 2006; Klumpp and Rudick, 2008). Sensations from these organs share synaptic circuits in the spinal cord (Wyndaele et al., 2013) and may even share individual sensory neurons (Figure 1; Christianson et al., 2007). These functional and anatomical interactions have implications for the effectiveness of local topical therapies designed to act on one organ only.

\section{OVARIAN HORMONES ALTER SENSORY INNERVATION AND PAIN THRESHOLDS}

Fluctuations in levels of ovarian hormones, particularly estrogen, are associated with changes in sensation, including pain, in a variety of tissues (Martin, 2009). This effect of estrogen on pain responses is no doubt due to the widespread expression of estrogen receptors which are located, not only in the FRT, but also on primary sensory neurons, spinal cord neurons, and higher brain centers (Papka et al., 2001; Papka and Mowa, 2003; Vanderhorst et al., 2009; Takanami et al., 2010). Notably, estrogen receptors are particularly concentrated in sacral spinal cord segments that are crucial to the control of pelvic organs (Vanderhorst et al., 2009). The role of estrogen in modulation of the nervous system is unclear (Balthazart and Ball, 2006). Estrogen can influence several receptors and ion channels in peripheral, spinal and supraspinal pathways. For example transient receptor potential (TRP) channels on primary afferent neurons are inhibited by activation of the beta subtype estrogen receptor (ER $\beta$; Xu et al., 2008).

\section{OVARIAN HORMONE WITHDRAWAL ALTERS FRT AND CUTANEOUS SENSITIVITY}

In humans menopause is associated with a drastic decrease in levels of ovarian hormones (Martin, 2009). With this altered hormonal status many women have increased pain from the FRT, especially the vagina, and some somatic tissues (Fillingim and Edwards, 2001; Samsioe, 2007; Martin, 2009). This post-menopausal 
vaginal hyperalgesia, typically presents as pain during intercourse (dyspareunia; Davis et al., 2005; Mac Bride etal., 2010). Various explanations have been proposed including vaginal atrophy (Forsberg, 1995). However the severity of pain is only loosely correlated with vaginal wall thickness (Kao et al., 2008), suggesting other factors are critical in this condition. Many of the painful urinogenital symptoms can be reversed by conventional systemic estrogen replacement although an increasing alternative is the use of local intravaginal estrogen replacement (Mac Bride et al., 2010).

\section{PERIPHERAL THERAPEUTIC TARGETS}

Precise information about the nature of primary sensory afferent endings in uterus, cervix, and vagina is scant compared with somatic (Woolf and Ma, 2007) or other visceral targets (Blackshaw etal., 2007). Anatomical data from animals (Papka et al., 1985, 1995, 1999; Shew etal., 1991; Collins et al., 2002) and, rarely, humans (Fried et al., 1990; Bokor et al., 2009; Malvasi et al., 2010) suggest they express the same neurochemical markers and receptors as nearby viscera, e.g., bladder and bowel.

\section{OPIOIDS}

Enkephalin immunoreactive axons in uterus and vagina have been reported in some mammals (Lakomy et al., 1994; Skobowiat et al., 2009), while mu and delta opioid receptors are present in human and mouse myometrium (Zhu and Pintar, 1998; Fanning et al., 2013). Functional measures of peripheral opioid receptor activation are not well documented for FRT afferents. However in GIT (Armstrong et al., 2005; Page et al., 2008) and bladder (Su et al., 1997) mechanosensitive sensory axons are modulated by opioid receptor agonists.

\section{TRP CHANNELS}

The TRP family of channels have been a focus of somatic pain research for some time. TRPV1 channels are present on presumed nociceptive axons in rat vagina (Liao and Smith, 2011) and human cervix (Tingåker et al., 2008). Interestingly these have been proposed to underlie some of the adverse side effects of clotrimazole, an anti-mycotic agent (Meseguer et al., 2008). Furthermore estrogen amplifies pain evoked by uterine distension, via a TRPV1 receptor dependent mechanism (Yan et al., 2007). Information on other TRP channels (e.g., TRPM8 and TRPA1) is limited in the FRT although they are expressed on sensory nerves supplying the GIT (Blackshaw et al., 2010).

\section{TROPHIC FACTORS}

Various growth factors particularly nerve growth factor (NGF) and members of the glial cell line-derived neurotrophic factor family of ligands are implicated not only in survival of some sensory neurons but their receptors have been suggested as targets for alleviating neuropathic pain (Koltzenburg et al., 1999; Boucher et al., 2000; Malin et al., 2006; Malin and Davis, 2008). Within the FRT NGF has been reported in the uterus (Lobos et al., 2005) and cervix (Chalar et al., 2003) and neurturin mRNA has been found in uterus (Widenfalk et al., 2000). Sensory neurons innervating the uterus were shown to express tyrosine receptor kinase A receptors (Chalar et al., 2003). Whether growth factors or their receptors modulate sensory afferent neurons from the FRT is unknown although they are implicated in bladder signaling (Klinger and Vizzard, 2008; Schnegelsberg et al., 2010).

\section{P2X RECEPTORS}

ATP was implicated in pain signaling nearly four decades ago (Bleehen and Keele, 1977). The subsequent discovery of P2X receptors on sensory nerves (Cook et al., 1997) had led to much work on identifying subtypes of $\mathrm{P} 2 \mathrm{X}$ receptors as therapeutic targets (North and Jarvis, 2013). Detailed studies of the FRT are lacking however P2X receptors have been identified on both uterine and cervical sensory axons (Papka et al., 2005).

\section{METABOTROPIC GLUTAMATE RECEPTORS (mGluRs)}

mGluR have been implicated in uterine and cervix sensory signaling (Ghosh etal., 2007) where they may modulate sensory discharge during parturition. Within the GIT peripheral mGluR on sensory endings modulate excitability (Page et al., 2005) where they have been proposed as therapeutic targets (Blackshaw et al., 2011).

\section{ACID SENSING ION CHANNELS (ASICs)}

No studies to date have tested whether ASIC are expressed on sensory neurons innervating the FRT. However, they are expressed in vagal (Page et al., 2007) and colonic (Jones et al., 2005) sensory neurons where they represent a potential therapeutic target.

\section{NITRIC OXIDE}

Nitric oxide generated by neuronal, inducible or endothelial nitric oxide synthase (NOS) plays many roles in the FRT. It is most notably released by autonomic vasodilator neurons to dramatically increase blood flow (Morris et al., 2005). However nNOS is also expressed in a subpopulation of sensory nerves (Papka et al., 1995). The role of nNOS in sensory signaling in the reproductive tract is unknown. However a role for pain modulation has been proposed in somatic pain models (Boettger et al., 2007; Keilhoff et al., 2013) and therapeutic agents that target nNOS have been proposed (Mladenova et al., 2012).

\section{CANNABINOIDS}

The cannabinoid signaling pathways have long been proposed as therapeutic targets (Roques et al., 2012). The FRT has some of the highest levels of endogenous cannabinoids (Schmid et al., 1997) and cannabinoid receptors are expressed in human and rodent myometrium (Das et al., 1995; Dennedy et al., 2004) where they act on smooth muscle. Cannabinoid receptors on sensory axons associated with the FRT have not been reported. However activation of cannabinoid type 1 receptors modulates sensory afferent signaling from the urinary bladder (Walczak et al., 2009) and jejunum (Yuce et al., 2010).

\section{CURRENT THERAPIES FOR FRT PAIN}

Currently evidence based treatment for FRT pain is limited. Standard pain therapies such as paracetamol, non-steroidal antiinflammatory drugs (NSAIDs), opioids, or neuropathic pain therapies have been used, as the type of pain is not well defined and directing treatment is difficult. Topical therapies are increasing as options for treating vulvar and vaginal pain and are recommended 
as first line treatment (Nunns et al., 2010). Topical therapy presents an attractive alternative to systemic therapy as they are generally well tolerated and are associated with less systemic adverse effects. However, some topical therapies may cause irritation that can worsen symptoms (Nunns et al., 2010). Currently, due to a lack of evidence of effectiveness, all topical therapies used in this condition would be considered experimental (Andrews, 2011). Topical treatments have also been associated with a high placebo response (Nunns et al., 2010).

Vulvodynia and vestibulodynia treatment has been the subject of several recent reviews, which concluded there was insufficient evidence of effectiveness and safety for a range of therapies. It was determined there was evidence of a lack of efficacy for botulinum toxin injection, topical 5\% xylocaine, and topical nifedipine. There was insufficient evidence to evaluate the effectiveness of steroid, local anesthetic injections, nerve blocks, intramuscular or intralesional interferon or topical capsaicin, montelukast, steroids, gabapentin, and ketoconazole (Andrews, 2011). Oral treatments that include tricyclic antidepressants, serotonin-norepinephrine uptake inhibitors and anticonvulsants (Cox and Neville, 2012) lack good quality evidence of effectiveness and have systemic adverse effects. Physical and alternative therapies are also used but there are only anecdotal reports of effectiveness (Andrews, 2011; Cox and Neville, 2012). Surgery has also been used effectively to treat vulvar vestibular pain (Nunns et al., 2010; Andrews, 2011; Cox and Neville, 2012). Estrogen therapies are effective in patients where the pain is linked to low estrogen levels following menopause or breast cancer treatment (Goetsch, 2012). Less common therapeutic options that have shown success in small clinical trials include cutaneous fibroblast lysate cream (Donders and Bellen, 2012), nitroglycerin cream (Walsh et al., 2002), and amitriptyline-baclofen cream (Nyirjesy et al., 2009).

Treatment of uterine pain is limited to systemic options with little evidence. Dysmenorrhea is the best-studied uterine pain syndrome. Primary dysmenorrhea is treated with simple analgesics, usually naproxen, while secondary dysmenorrhea treatment relies on removal of the underlying cause of the pain (Kohle and Deb, 2011). As other pelvic organs can cause pelvic pain a thorough investigation is important. Non-pharmacological therapies including nutrition and lifestyle changes, along with surgery may play a role. Further investigation is needed to determine the most appropriate treatments for uterine pain.

Further investigation is needed to determine specific targets for pharmacological management of the various FRT pain sub-types. The use of drug delivery systems may be required to effectively deliver existing or experimental compounds to the target site for improved efficacy and/or to reduce systemic adverse effects.

\section{DELIVERING THERAPIES TO THE FRT}

The intravaginal route of drug administration has been studied as a suitable site for local and systemic delivery of therapeutic agents. The degree to which therapies act locally or systemically is formulation dependent. Presently intravaginal therapies are typically prescribed for vaginal infections and vaginal dryness. Systemic drug delivery includes uterine targeting or treatment of migraines (Bassi and Kaur, 2012). In relation to pain stemming from the FRT, the intravaginal route shows promise for the local or systemic delivery of analgesic and anti-inflammatory agents.

The vagina has unique features that can be exploited for optimal therapeutic responses, such as the presence of a dense network of blood vessels, large surface area, and permeability (Srikrishna and Cardozo, 2013). In addition, unlike conventional oral therapy, the vaginal route avoids hepatic first-pass metabolism, significant enzymatic degradation of active ingredients and drug interactions (Bassi and Kaur, 2012). Absorption from vaginal delivery systems occurs by dissolution, followed by penetration of drug through the vaginal membrane to reach the systemic circulation (Hussain and Ahsan, 2005). Physiological factors can affect the drug release from intravaginal delivery systems and/or vaginal absorption of drugs, such as cyclic changes in thickness of the vaginal epithelium, fluid volume and composition, $\mathrm{pH}$ and sexual arousal (Hussain and Ahsan, 2005; das Neves et al., 2011). Although physiological factors are difficult to alter, the physicochemical properties of a drug compound (e.g., molecular weight, lipophilicity, ionization, surface charge, chemical nature; Hussain and Ahsan, 2005) as well as the formulation can be selected to regulate local versus systemic activity.

Despite its therapeutic potential, vaginal preparations show low patient acceptability due to factors including multiple daily dosing; leakage and messiness following application; and the need for night-time dosing. The effectiveness of commonly available vaginal dosage forms (creams, gels, solutions, foams, pessaries) is often limited by their low retention to the vaginal epithelium (Pavelić et al., 2004). In order to overcome these limitations, novel vaginal delivery systems are being developed that possess desirable distribution, bioadhesion, and release properties - such as vaginal rings, bioadhesive delivery systems, and nanosystems.

\section{VAGINAL RINGS}

Intravaginal rings (IVRs) are circular drug delivery devices that are designed to provide both sustained and controlled drug release, lasting for several weeks to several months following insertion into the vagina. IVR have been shown to be effective in delivering a multitude of compounds, such as contraceptive steroids and steroids for the treatment of post-menopausal atrophy. This delivery device has been previously reviewed (Baloglu et al., 2009; Thurman et al., 2013; Srikrishna and Cardozo, 2013).

\section{BIOADHESIVE DRUG DELIVERY (BDD) SYSTEMS}

BDD systems were developed to circumvent the issues associated with conventional vaginal formulations, by adhering to the vaginal mucosal tissue and prolonging the residence time of the formulation. Vaginal BDD systems have been exploited for both local as well as systemic delivery of drugs (Merabet et al., 2005; Bassi and Kaur, 2012). Several studies have focused on BDD systems in the form of tablets, films, patches, and gels for the vaginal mucosal route that are composed of bioadhesive polymers that are biocompatible, biodegradable and stable. Common mucoadhesive polymers include tragacanth (acacia), carbopol resins, sodium alginate, carboxymethylcellulose, and chitosan. Vaginal BDD systems have been previously reviewed (Baloglu et al., 2009; Bassi and Kaur, 2012). 


\section{NANOSYSTEMS}

Nanocarriers [e.g., dendrimers, liposomes, Poly(lactic-co-glycolic acid) nanoparticles, silver and gold nanoparticles] have been utilized in topical drug delivery to enhance the penetration of drug compounds. For example, encapsulation of drugs within liposomes can provide characteristics such as enhanced skin or mucosal permeability, sustained release as well as controlled release (Pavelić et al., 2004). Such nanosystems are usually incorporated within a bioadhesive base (e.g., Carbopol resin) to enhance the viscosity of the formulation for retention on the mucosal surface (Pavelić et al., 2004; das Neves et al., 2011). The use of nanosystems is promising for intravaginal drug delivery, however, similar to BDD systems, the interaction of these formulations with mucosal fluids present in the vagina at different stages of the menstrual cycle and age is not yet well defined (Bassi and Kaur, 2012).

\section{CONCLUSION}

Pain attributed to the FRT is complex and involves several classes of nociceptive and non-nociceptive sensory neurons. The unique neural anatomy of pelvic organs provides challenges in the delivery of selective therapies. There is little evidence that current treatments are effective and new strategies need to be developed. Relative to somatic pain, or pain from the GIT, there is a lack of information on the basic neurophysiology of FRT sensory neurons. Well defined animal models of neuropathic or inflammatory pain exist for somatic structures (e.g., chronic constriction injury models) and to some extent colitis (trinitrobenzene sulfonic acid models). At present there is no consistent approach to FRT pain. This will need to be addressed if we are to explore the many potential therapeutic targets present on FRT sensory neurons. Exciting opportunities exist for development of intravaginal drug delivery systems for either local or systemic drug delivery. Similar targeted delivery systems can be developed for the vulvodynias. Finally larger clinical trials of the few currently available promising therapies could provide useful insights in directing preclinical studies.

\section{ACKNOWLEDGMENTS}

We would like to thank Kelly Smith for her artwork and Jessica Madden for editing the manuscript.

\section{REFERENCES}

Andrews, J. C. (2011). Vulvodynia interventions-systematic review and evidence grading. Obstet. Gynecol. Surv. 66, 299-315. doi: 10.1097/OGX.0b013e3182277fb7

Armstrong, D. S., Arvieux, J., Asaturyan, R., Averett, T., Bailey, S. L., Batigne, G., et al. (2005). Strange-quark contributions to parity-violating asymmetries in the forward g0 electron-proton scattering experiment. Phys. Rev. Lett. 95, 092001. doi: 10.1103/PhysRevLett.95.092001

Bachmann, G. A., Rosen, R., Pinn, V. W., Utian, W. H., Ayers, C., Basson, R. (2006). Vulvodynia: a state-of-the-art consensus on definitions, diagnosis and management. J. Reprod. Med. 51, 447-456.

Baloglu, E., Senyigit, Z. A., Karavana, S. Y., and Bernkop-Schnürch, A. (2009). Strategies to prolong the intravaginal residence time of drug delivery systems. $J$. Pharm. Pharmaceut. Sci. 12, 312-336.

Balthazart, J., and Ball, G. F. (2006). Is brain estradiol a hormone or a neurotransmitter? Trends Neurosci. 29, 241-249. doi: 10.1016/j.tins.2006.03.004

Baskin, L. S., and Tanagho, E. A. (1992). Pelvic pain without pelvic organs. J. Urol. 147, 683-686.

Bassi, P., and Kaur, G. (2012). Innovations in bioadhesive vaginal drug delivery system. Expert. Opin. Ther. Pat. 22, 1019-1032. doi: 10.1517/13543776.2012.714369
Berkley, K. J., Hubscher, C. H., and Wall, P. D. (1993a). Neuronal responses to stimulation of the cervix, uterus, colon, and skin in the rat spinal cord. J. Neurophysiol. 69, 545-556.

Berkley, K. J., Robbins, A., and Sato, Y. (1993b). Functional differences between afferent fibers in the hypogastric and pelvic nerves innervating female reproductive organs in the rat. J. Neurophysiol. 69, 533-544.

Blackshaw, L. A., Brierley, S. M., and Hughes, P. A. (2010). TRP channels: new targets for visceral pain. Gut 59, 126-135. doi: 10.1136/gut.2009.179523

Blackshaw, L. A., Brookes, S. J., Grundy, D., and Schemann, M. (2007). Sensory transmission in the gastrointestinal tract. Neurogastroenterol. Motil. 19, 1-19. doi: 10.1111/j.1365-2982.2006.00871.x

Blackshaw, L. A., Page, A. J., and Young, R. L. (2011). Metabotropic glutamate receptors as novel therapeutic targets on visceral sensory pathways. Front. Neurosci. 5:40. doi: 10.3389/fnins.2011.00040

Bleehen, T., and Keele, C. A. (1977). Observations on the algogenic actions of adenosine compounds on the human blister base preparation. Pain 3, 367-377. doi: 10.1016/0304-3959(77)90066-5

Boettger, M. K., Uceyler, N., Zelenka, M., Schmitt, A., Reif, A., Chen, Y., et al. (2007). Differences in inflammatory pain in nNOS-, iNOS- and eNOS-deficient mice. Eur. J. Pain 11, 810-818. doi: 10.1016/j.ejpain.2006.12.008

Bokor, A., Kyama, C. M., Vercruysse, L., Fassbender, A., Gevaert, O., Vodolazkaia, A., et al. (2009). Density of small diameter sensory nerve fibres in endometrium: a semi-invasive diagnostic test for minimal to mild endometriosis. Hum. Reprod. 24, 3025-3032. doi: 10.1093/humrep/dep283

Boucher, T. J., Okuse, K., Bennett, D. L., Munson, J. B., Wood, J. N., and McMahon, S. B. (2000). Potent analgesic effects of GDNF in neuropathic pain states. Science 290, 124-127. doi: 10.1126/science.290.5489.124

Brierley, S. M., Jones, R. C. III, Gebhart, G. F., and Blackshaw, L. A. (2004). Splanchnic and pelvic mechanosensory afferents signal different qualities of colonic stimuli in mice. Gastroenterology 127, 166-178. doi: 10.1053/j.gastro.2004.04.008

Cervero, F., and Laird, J. M. (1999). Visceral pain. Lancet 353, 2145-2148. doi: 10.1016/S0140-6736(99)01306-9

Cervero, F., and Laird, J. M. (2004). Understanding the signaling and transmission of visceral nociceptive events. J. Neurobiol. 61, 45-54. doi: 10.1002/neu.20084

Chalar, C., Richeri, A., Viettro, L., Chavez-Genaro, R., Bianchimano, P., Marmol, N. M., et al. (2003). Plasticity in developing rat uterine sensory nerves: the role of NGF and TrkA. Cell Tissue Res. 314, 191-205. doi: 10.1007/s00441-003-0799-9

Christianson, J. A., Liang, R., Ustinova, E. E., Davis, B. M., Fraser, M. O., and Pezzone, M. A. (2007). Convergence of bladder and colon sensory innervation occurs at the primary afferent level. Pain 128, 235-243. doi: 10.1016/j.pain.2006.09.023

Collins, J. J., Usip, S., McCarson, K. E., and Papka, R. E. (2002). Sensory nerves and neuropeptides in uterine cervical ripening. Peptides 23, 167-183. doi: 10.1016/S0196-9781(01)00593-9

Cook, S. P., Vulchanova, L., Hargreaves, K. M., Elde, R., and McCleskey, E. W. (1997). Distinct ATP receptors on pain-sensing and stretch-sensing neurons. Nature 387, 505-508. doi: 10.1038/387505a0

Cox, K. J., and Neville, C. E. (2012). Assessment and management options for women with vulvodynia. J. Midwifery Womens Health 57, 231-240. doi: 10.1111/j.15422011.2012.00162.x

das Neves, J., Amiji, M., and Sarmento, B. (2011). Mucoadhesive nanosystems for vaginal microbicide development: friend or foe? Wiley Interdiscip. Rev. Nanomed. Nanobiotechnol. 3, 389-399. doi: 10.1002/wnan.144

Das, S. K., Paria, B. C., Chakraborty, I., and Dey, S. K. (1995). Cannabinoid ligandreceptor signaling in the mouse uterus. Proc. Natl. Acad. Sci. U.S.A. 92, 4332-4336. doi: $10.1073 /$ pnas.92.10.4332

Davis, S. R., Dinatale, I., Rivera-Woll, L., and Davison, S. (2005). Postmenopausal hormone therapy: from monkey glands to transdermal patches. J. Endocrinol. 185, 207-222. doi: 10.1677/joe.1.05847

Dennedy, M. C., Friel, A. M., Houlihan, D. D., Broderick, V. M., Smith, T., and Morrison, J. J. (2004). Cannabinoids and the human uterus during pregnancy. Am. J. Obstet. Gynecol. 190, 2-9; discussion 3A.

Donders, G. G., and Bellen, G. (2012). Cream with cutaneous fibroblast lysate for the treatment of provoked vestibulodynia: a double-blind randomized placebo-controlled crossover study. J. Low. Genit. Tract Dis. 16, 427-436. doi: 10.1097/LGT.0b013e31825a2274

Fanning, R. A., McMorrow, J. P., Campion, D. P., Carey, M. F., and O’Connor, J. J. (2013). Opioid mediated activity and expression of $\mathrm{mu}$ and delta opioid receptors in isolated human term non-labouring myometrium. Eur. J. Pharmacol. 698, 170-177. doi: 10.1016/j.ejphar.2012.09.045 
Fillingim, R. B., and Edwards, R. R. (2001). The association of hormone replacement therapy with experimental pain responses in postmenopausal women. Pain 92 , 229-234. doi: 10.1016/S0304-3959(01)00256-1

Forsberg, J. G. (1995). A morphologist's approach to the vagina-age-related changes and estrogen sensitivity. Maturitas 22(Suppl.), S7-S15. doi: 10.1016/03785122(95)00957-4

Fried, G., Meister, B., and Radestad, A. (1990). Peptide-containing nerves in the human pregnant uterine cervix: an immunohistochemical study exploring the effect of RU 486 (mifepristone). Hum. Reprod. 5, 870-876.

Fugl-Meyer, K. S., Bohm-Starke, N., Damsted Petersen, C., Fugl-Meyer, A., Parish, S., and Giraldi, A. (2012). Standard operating procedures for female genital sexual pain. J. Sex. Med. 10, 83-93. doi: 10.1111/j.1743-6109.2012.02867.x

Ghosh, C., Storey-Workley, M., Usip, S., Hafemeister, J., Miller, K. E., and Papka, R. E. (2007). Glutamate and metabotropic glutamate receptors associated with innervation of the uterine cervix during pregnancy: receptor antagonism inhibits c-Fos expression in rat lumbosacral spinal cord at parturition. J. Neurosci. Res. 85, 1318-1335. doi: 10.1002/jnr.21225

Giamberardino, M. A. (2008). Women and visceral pain: are the reproductive organs the main protagonists? Mini-review at the occasion of the "European Week Against Pain in Women 2007”. Eur. J. Pain 12, 257-260. doi: 10.1016/j.ejpain.2007.11.007

Goetsch, M. F. (2012). Unprovoked vestibular burning in late estrogen-deprived menopause: a case series. J. Low. Genit. Tract Dis. 16, 442-446. doi 10.1097/LGT.0b013e31825c2d28

Goldstein, A. T., and Burrows, L. (2008). Vulvodynia. J. Sex. Med. 5, 5-14; quiz 15. doi: 10.1111/j.1743-6109.2007.00679.x

Harlow, B. L., and Stewart, E. G. (2003). A population-based assessment of chronic unexplained vulvar pain: have we underestimated the prevalence of vulvodynia? J. Am. Med. Womens Assoc. 58, 82-88.

Head, H. (1893). On disturbances of sensation with especial reference to the pain of visceral disease. Brain 16, 1-133. doi: 10.1093/brain/16.1-2.1

Hillen, T. I., Grbavac, S. L., Johnston, P. J., Straton, J. A., and Keogh, J. M. (1999). Primary dysmenorrhea in young Western Australian women: prevalence, impact, and knowledge of treatment. J. Adolesc. Health 25, 40-45. doi: 10.1016/S1054139X(98)00147-5

Hotta, H., Uchida, S., Shimura, M., and Suzuki, H. (1999). Uterine contractility and blood flow are reflexively regulated by cutaneous afferent stimulation in anesthetized rats. J. Auton. Nerv. Syst. 75, 23-31. doi: 10.1016/S0165-1838(98)00170-2

Hussain, A., and Ahsan, F. (2005). The vagina as a route for systemic drug delivery. J. Control. Release 103, 301-313. doi: 10.1016/j.jconrel.2004.11.034

International Association for the Study of Pain. (2011). Available at: http://www.iasp-pain.org/AM/Template.cfm?Section=Pain_Definitions

Janig, W., and Morrison, J. F. (1986). Functional properties of spinal visceral afferents supplying abdominal and pelvic organs, with special emphasis on visceral nociception. Prog. Brain Res. 67, 87-114. doi: 10.1016/S0079-6123(08)62758-2

Jobling, P., Gibbins, I. L., and Morris, J. L. (2003). Functional organization of vasodilator neurons in pelvic ganglia of female guinea pigs: comparison with uterine motor neurons. J. Comp. Neurol. 459, 223-241. doi: 10.1002/cne.10584

Jobling, P., Graham, B. A., Brichta, A. M., and Callister, R. J. (2010). Cervix stimulation evokes predominantly subthreshold synaptic responses in mouse thoracolumbar and lumbosacral superficial dorsal horn neurons. J. Sex. Med. 7, 2068-2076. doi: 10.1111/j.1743-6109.2010.01768.x

Jones, R. C. III, Xu, L., and Gebhart, G. F. (2005). The mechanosensitivity of mouse colon afferent fibers and their sensitization by inflammatory mediators require transient receptor potential vanilloid 1 and acid-sensing ion channel 3. J. Neurosci. 25, 10981-10989. doi: 10.1523/JNEUROSCI.0703-05.2005

Jones, T. L., and Sorkin, L. S. (2003). Basic neurochemistry of central sensitization. Semin. Pain Med. 1, 184-194. doi: 10.1016/S1537-5897(03)00043-0

Kao, A., Binik, Y. M., Kapuscinski, A., and Khalife, S. (2008). Dyspareunia in postmenopausal women: a critical review. Pain Res. Manag. 13, 243-254.

Keilhoff, G., Schroder, H., Peters, B., and Becker, A. (2013). Time-course of neuropathic pain in mice deficient in neuronal or inducible nitric oxide synthase. Neurosci. Res. 77, 215-221. doi: 10.1016/j.neures.2013.08.008

Klinger, M. B., and Vizzard, M. A. (2008). Role of p75NTR in female rat urinary bladder with cyclophosphamide-induced cystitis. Am. J. Physiol. Renal Physiol. 295, F1778-F1789. doi: 10.1152/ajprenal.90501.2008

Klumpp, D. J., and Rudick, C. N. (2008). Summation model of pelvic pain in interstitial cystitis. Nat. Clin. Pract. 5, 494-500. doi: 10.1038/ncpuro1203
Kohle, S., and Deb, S. (2011). Dysmenorrhoea. Obstet. Gynaecol. Reprod. Med. 21, 311-316. doi: 10.1016/j.ogrm.2011.09.006

Koltzenburg, M., Bennett, D. L., Shelton, D. L., and McMahon, S. B. (1999). Neutralization of endogenous NGF prevents the sensitization of nociceptors supplying inflamed skin. Eur. J. Neurosci. 11, 1698-1704. doi: 10.1046/j.14609568.1999.00590.x

Kramer, M. G., and Reiter, R. C. (1997). Hysterectomy: indications, alternatives and predictors. Am. Fam. Physician. 55, 827-834.

Lakomy, M., Happola, O., Majewski, M., and Kaleczyc, J., (1994). Immunohistochemical localization of neuropeptides in nerve fibers of the porcine vagina and uterine cervix. Folia Histochem. Cytobiol. 32, 167-175.

Lara, L. A., Useche, B., Ferriani, R. A., Reis, R. M., de Sa, M. F., de Freitas, M. M. (2009). The effects of hypoestrogenism on the vaginal wall: interference with the normal sexual response. J. Sex. Med. 6, 30-39. doi: 10.1111/j.1743-6109.2008.01052.x

Liao, Z., and Smith, P. G. (2011). Adaptive plasticity of vaginal innervation in term pregnant rats. Reprod. Sci. 18, 1237-1245. doi: 10.1177/1933719111410706

Lobos, E., Gebhardt, C., Kluge, A., and Spanel-Borowski, K. (2005). Expression of nerve growth factor (NGF) isoforms in the rat uterus during pregnancy: accumulation of precursor proNGF. Endocrinology 146, 1922-1929. doi: 10.1210/en.2004-0925

Lu, V. B., Biggs, J. E., Stebbing, M. J., Balasubramanyan, S., Todd, K. G., Lai, A. Y. et al. (2009). Brain-derived neurotrophic factor drives the changes in excitatory synaptic transmission in the rat superficial dorsal horn that follow sciatic nerve injury. J. Physiol. 587, 1013-1032. doi: 10.1113/jphysiol.2008.166306

Mac Bride, M. B., Rhodes, D. J., and Shuster, L. T. (2010). Vulvovaginal atrophy. Mayo Clin. Proc. 85, 87-94. doi: 10.4065/mcp.2009.0413

Malin, S. A., and Davis, B. M. (2008). Postnatal roles of glial cell line-derived neurotrophic factor family members in nociceptors plasticity. Sheng Li Xue Bao 60, 571-578.

Malin, S. A., Molliver, D. C., Koerber, H. R., Cornuet, P., Frye, R., Albers, K. M., et al. (2006). Glial cell line-derived neurotrophic factor family members sensitize nociceptors in vitro and produce thermal hyperalgesia in vivo. J. Neurosci. 26, 8588-8599. doi: 10.1523/JNEUROSCI.1726-06.2006

Malvasi, A., Tinelli, A., Cavallotti, C., Bettocchi, S., Di Renzo, G. C., and Stark, M. (2010). Substance P (SP) and vasoactive intestinal polypeptide (VIP) in the lower uterine segment in first and repeated cesarean sections. Peptides 31, 2052-2059. doi: 10.1016/j.peptides.2010.07.025

Martin, V. T. (2009). Ovarian hormones and pain response: a review of clinical and basic science studies. Gend. Med. 6(Suppl.2), 168-192. doi: 10.1016/j.genm.2009.03.006

Martin-Alguacil, N., Schober, J. M., Sengelaub, D. R., Pfaff, D. W., and Shelley, D. N. (2008). Clitoral sexual arousal: neuronal tracing study from the clitoris through the spinal tracts. J. Urol. 180, 1241-1248. doi: 10.1016/j.juro.2008.06.009

Mathias, S. D., Kuppermann, M., Liberman, R. F., Lipschutz, R. C., and Steege, J. F. (1996). Chronic pelvic pain: prevalence, health-related quality of life, and economic correlates. Obstet. Gynecol. 87, 321-327. doi: 10.1016/00297844(95)00458-0

McMahon, S. B. (1997). Are there fundamental differences in the peripheral mechanisms of visceral and somatic pain? Behav. Brain Sci. 20, 381-391; discussion 435-513. doi: 10.1017/S0140525X97231481

Merabet, J., Thompson, D., and Saul Levinson, R. (2005). Advancing vaginal drug delivery. Expert Opin. Drug Deliv. 2, 769-777. doi: 10.1517/17425247.2.4.769

Merskey, H., and Bogduk, N. (1994). Classification of Chronic Pain. Descriptions of Chronic Pain Syndromes and Definitions of Pain Terms. Seattle, WA: IASP Press.

Meseguer, V., Karashima, Y., Talavera, K., D’Hoedt, D., Donovan-Rodriguez, T., Viana, F., et al. (2008). Transient receptor potential channels in sensory neurons are targets of the antimycotic agent clotrimazole. J. Neurosci. 28, 576-586. doi: 10.1523/JNEUROSCI.4772-07.2008

Millan, M. J. (1999). The induction of pain: an integrative review. Prog. Neurobiol. 57, 1-164. doi: 10.1016/S0301-0082(98)00048-3

Mladenova, G., Annedi, S. C., Ramnauth, J., Maddaford, S. P., Rakhit, S., Andrews, J. S., et al. (2012). First-in-class, dual-action, 3,5-disubstituted indole derivatives having human nitric oxide synthase (nNOS) and norepinephrine reuptake inhibitory (NERI) activity for the treatment of neuropathic pain. J. Med. Chem. 55, 3488-3501. doi: 10.1021/jm300138g

Morris, J. L., Gibbins, I. L., and Jobling, P. (2005). Post-stimulus potentiation of transmission in pelvic ganglia enhances sympathetic dilatation of guinea-pig 
uterine artery in vitro. J. Physiol. 566, 189-203. doi: 10.1113/jphysiol.2005. 083493

Moszkowicz, D., Alsaid, B., Bessede, T., Zaitouna, M., Penna, C., Benoît, G. (2011). Neural supply to the clitoris: immunohistochemical study with three-dimensional reconstruction of cavernous nerve, spongious nerve, and dorsal clitoris nerve in human fetus. J. Sex. Med. 8, 1112-1122. doi: 10.1111/j.1743-6109.2010.02182.x

North, R. A., and Jarvis, M. F. (2013). P2X receptors as drug targets. Mol. Pharmacol. 83, 759-769. doi: 10.1124/mol.112.083758

Nunns, D., Mandal, D., Byrne, M., McLelland, J., Rani, R., Cullimore, J., et al. (2010). Guidelines for the management of vulvodynia. Br. J. Dermatol. 162, 1180-1185. doi: 10.1111/j.1365-2133.2010.09684.x

Nyirjesy, P., Lev-Sagie, A., Mathew, L., and Culhane, J. F. (2009). Topical amitriptyline-baclofen cream for the treatment of provoked vestibulodynia. $J$. Low. Genit. Tract Dis. 13, 230-236. doi: 10.1097/LGT.0b013e31819663ee

Page, A. J., Brierley, S. M., Martin, C. M., Hughes, P. A., and Blackshaw, L. A. (2007). Acid sensing ion channels 2 and 3 are required for inhibition of visceral nociceptors by benzamil. Pain 133, 150-160. doi: 10.1016/j.pain.2007.03.019

Page, A. J., Martin, C. M., and Blackshaw, L. A. (2002). Vagal mechanoreceptors and chemoreceptors in mouse stomach and esophagus. J. Neurophysiol. 87, 2095-2103.

Page, A. J., O’Donnell, T. A., and Blackshaw, L. A. (2008). Opioid modulation of ferret vagal afferent mechanosensitivity. Am. J. Physiol. Gastrointest. Liver Physiol. 294, G963-G970. doi: 10.1152/ajpgi.00562.2007

Page, A. J., Young, R. L., Martin, C. M., Umaerus, M., O’Donnell, T. A., et al. (2005). Metabotropic glutamate receptors inhibit mechanosensitivity in vagal sensory neurons. Gastroenterology 128, 402-410. doi: 10.1053/j.gastro.2004.11.062

Papka, R. E., and Mowa, C. N. (2003). Estrogen receptors in the spinal cord, sensory ganglia, and pelvic autonomic ganglia. Int. Rev. Cytol. 231, 91-127. doi: 10.1016/S0074-7696(03)31003-4

Papka, R. E., and Traurig, H. H. (1993). "Autonomic efferent and visceral sensory innervation of the female reproductive system: special reference to neurochemical markers in nerves and ganglionic connections," in Nervous Control of the Urogenital System, ed. C. Maggi (Chur: Harwood, Luxembourg), 423-466.

Papka, R. E., Collins, J., Copelin, T., and Wilson, K. (1999). Calretininimmunoreactive nerves in the uterus, pelvic autonomic ganglia, lumbosacral dorsal root ganglia and lumbosacral spinal cord. Cell Tissue Res. 298, 63-74. doi: 10.1007/s004419900071

Papka, R. E., Cotton, J. P., and Traurig, H. H. (1985). Comparative distribution of neuropeptide tyrosine-, vasoactive intestinal polypeptide-, substance P-immunoreactive, acetylcholinesterase-positive and noradrenergic nerves in the reproductive tract of the female rat. Cell Tissue Res. 242, 475-490. doi: 10.1007/BF00225412

Papka, R. E., Hafemeister, J., and Storey-Workley, M. (2005). P2X receptors in the rat uterine cervix, lumbosacral dorsal root ganglia, and spinal cord during pregnancy. Cell Tissue Res. 321, 35-44. doi: 10.1007/s00441-005-1114-8

Papka, R. E., McNeill, D. L., Thompson, D., and Schmidt, H. H. (1995). Nitric oxide nerves in the uterus are parasympathetic, sensory, and contain neuropeptides. Cell Tissue Res. 279, 339-349. doi: 10.1007/BF00318490

Papka, R. E., Storey-Workley, M., Shughrue, P. J., Merchenthaler, I., Collins, J. J., Usip, S., et al. (2001). Estrogen receptor-alpha and beta- immunoreactivity and mRNA in neurons of sensory and autonomic ganglia and spinal cord. Cell Tissue Res. 304, 193-214. doi: 10.1007/s004410100363

Paterson, L. Q., Davis, S. N., Khalife, S., Amsel, R., and Binik, Y. M. (2009). Persistent genital and pelvic pain after childbirth. J. Sex. Med. 6, 215-221. doi: 10.1111/j.1743-6109.2008.01063.x

Pavelić, Z., Skalko-Basnet, N., Schubert, R., and Jalsenjak, I. (2004). Liposomal gels for vaginal drug delivery. Methods Enzymol. 387, 287-299. doi: 10.1016/S00766879(04)87018-6

Petersen, C. D., Lundvall, L., Kristensen, E., and Giraldi, A. (2008). Vulvodynia. Definition, diagnosis and treatment. Acta obstet. Gynecol. Scand. 87, 893-901. doi: 10.1080/00016340802323321

Pitts, M. K., Ferris, J. A., Smith, A. M., Shelley, J. M., and Richters, J. (2008). Prevalence and correlates of three types of pelvic pain in a nationally representative sample of Australian women. Med. J. Aust. 189, 138-143.

Roques, B. P., Fournie-Zaluski, M. C., and Wurm, M. (2012). Inhibiting the breakdown of endogenous opioids and cannabinoids to alleviate pain. Nat. Rev. Drug Discov. 11, 292-310. doi: 10.1038/nrd3673

Ryder, R. M. (1996). Chronic pelvic pain. Am. Fam. Physician. 54, 2225-2232, 2237.
Samsioe, G. (2007). "Urogenital symptoms around the menopause and beyond," in Treatment of the Postmenopausal Woman, ed. R. A. Lobo (Burlington: Elsevier).

Schmid, P. C., Paria, B. C., Krebsbach, R. J., Schmid, H. H., and Dey, S. K. (1997). Changes in anandamide levels in mouse uterus are associated with uterine receptivity for embryo implantation. Proc. Natl. Acad. Sci. U.S.A. 94, 4188-4192.

Schnegelsberg, B., Sun, T. T., Cain, G., Bhattacharya, A., Nunn, P. A., Ford, A. P., etal. (2010). Overexpression of NGF in mouse urothelium leads to neuronal hyperinnervation, pelvic sensitivity, and changes in urinary bladder function. Am. J. Physiol. Regul. Integr. Comp. Physiol. 298, R534-R547. doi: 10.1152/ajpregu.00367.2009

Shew, R. L., Papka, R. E., and McNeill, D. L. (1991). Substance P and calcitonin gene-related peptide immunoreactivity in nerves of the rat uterus: localization, colocalization and effects on uterine contractility. Peptides 12, 593-600. doi: 10.1016/0196-9781(91)90107-Z

Skobowiat, C., Gonkowski, S., Janiuk, I., Calka, J., and Majewski, M., (2009). The relationship and co-localization of vasoactive intestinal peptide (VIP)- and Leu5enkephalin (LENK)-immunoreactivity in the female genital tract of the pig. Pol. J. Vet. Sci. 12, 347-353.

Song, X., Chen, B. N., Zagorodnyuk, V. P., Lynn, P. A., Blackshaw, L. A., Grundy, D. et al. (2009). Identification of medium/high-threshold extrinsic mechanosensitive afferent nerves to the gastrointestinal tract. Gastroenterology 137, 274-284, 284.el. doi: 10.1053/j.gastro.2009.02.061

Srikrishna, S., and Cardozo, L. (2013). The vagina as a route for drug delivery: a review. Int. Urogynecol. J. 24, 537-543. doi: 10.1007/s00192-012-2009-3

Stones, R. W., Selfe, S. A., Fransman, S., and Horn, S. A. (2000). Psychosocial and economic impact of chronic pelvic pain. Baillieres Best Pract. Res. Clin. Obstet. Gynaecol. 14, 415-431. doi: 10.1053/beog.1999.0084

Su, X., Sengupta, J. N., and Gebhart, G. F. (1997). Effects of opioids on mechanosensitive pelvic nerve afferent fibers innervating the urinary bladder of the rat. $J$. Neurophysiol. 77, 1566-1580.

Sugiura, Y., Terui, N., and Hosoya, Y. (1989). Difference in distribution of central terminals between visceral and somatic unmyelinated $(C)$ primary afferent fibers. J. Neurophysiol. 62, 834-840.

Sugiura, Y., Terui, N., Hosoya, Y., Tonosaki, Y., Nishiyama, K., and Honda, T. (1993). Quantitative analysis of central terminal projections of visceral and somatic unmyelinated (C) primary afferent fibers in the guinea pig. J. Comp. Neurol. 332, 315-325. doi: 10.1002/cne.903320305

Takanami, K., Sakamoto, H., Matsuda, K.-I., Hosokawa, K., Nishi, M., Prossnitz, E. R., et al. (2010). Expression of G protein-coupled receptor 30 in the spinal somatosensory system. Brain Res. 1310, 17-28. doi: 10.1016/j.brainres.2009.11.004

Thurman, A. R., Clark, M. R., Hurlburt, J. A., and Doncel, G. F. (2013). Intravaginal rings as delivery systems for microbicides and multipurpose prevention technologies. Int. J. Womens Health 5, 695-708. doi: 10.2147/IJWH. S34030

Tingåker, B. K., Ekman-Ordeberg, G., Facer, P., Irestedt, L., and Anand, P. (2008). Influence of pregnancy and labor on the occurrence of nerve fibers expressing the capsaicin receptor TRPV1 in human corpus and cervix uteri. Reprod. Biol. Endocrinol. 6:8. doi: 10.1186/1477-7827-6-8

Vanderhorst, V. G. J. M., Terasawa, E., and Ralston, H. J. (2009). Estrogen receptoralpha immunoreactive neurons in the brainstem and spinal cord of the female rhesus monkey: species-specific characteristics. Neuroscience 158, 798-810. doi: 10.1016/j.neuroscience.2008.10.017

Vilimas, P. I., Yuan, S. Y., Haberberger, R. V., and Gibbins, I. L. (2011). Sensory innervation of the external genital tract of female guinea pigs and mice. J. Sex. Med. 8, 1985-1995. doi: 10.1111/j.1743-6109.2011.02258.x

Walczak, J. S., Price, T. J., and Cervero, F. (2009). Cannabinoid CB1 receptors are expressed in the mouse urinary bladder and their activation modulates afferent bladder activity. Neuroscience 159, 1154-1163. doi: 10.1016/j.neuroscience.2009.01.050

Walsh, K. E., Berman, J. R., Berman, L. A., and Vierregger, K. (2002). Safety and efficacy of topical nitroglycerin for treatment of vulvar pain in women with vulvodynia: a pilot study. J. Gend. Specif. Med. 5, 21-27.

Wesselmann, U. (2001). Neurogenic inflammation and chronic pelvic pain. World J. Urol. 19, 180-185. doi: 10.1007/s003450100201

Wesselmann, U., and Lai, J. (1997). Mechanisms of referred visceral pain: uterine inflammation in the adult virgin rat results in neurogenic plasma extravasation in the skin. Pain 73, 309-317. doi: 10.1016/S0304-3959(97)00112-7 
Wesselmann, U., Czakanski, P. P., and Sanders, C. (2000). Altered CNS processing of nociceptive messages from the vagina in rats, that have recovered from uterine inflammation. Prog. Pain Res. Manag. 16, 581-588.

Westlund, K. N. (2000). Visceral nociception. Curr. Rev. Pain 4, 478-487. doi: 10.1007/s11916-000-0072-9

Whorwell, P. J., Lupton, E. W., Erduran, D., and Wilson, K. (1986). Bladder smooth muscle dysfunction in patients with irritable bowel syndrome. Gut 27, 1014-1017. doi: 10.1136/gut.27.9.1014

Widenfalk, J., Parvinen, M., Lindqvist, E., and Olson, L. (2000). Neurturin, RET GFRalpha-1 and GFRalpha-2, but not GFRalpha-3, mRNA are expressed in mice gonads. Cell Tissue Res. 299, 409-415.

Winnard, K. P., Dmitrieva, N., and Berkley, K. J. (2006). Cross-organ interactions between reproductive, gastrointestinal, and urinary tracts: modulation by estrous stage and involvement of the hypogastric nerve. Am. J. Physiol. Regul. Integr. Comp. Physiol. 291, R1592-R1601. doi: 10.1152/ajpregu.00455.2006

Woolf, C. J., and Ma, Q. (2007). Nociceptors-noxious stimulus detectors. Neuron 55, 353-364. doi: 10.1016/j.neuron.2007.07.016

Wyndaele, M., De Wachter, S., De Man, J., Minagawa, T., Wyndaele, J. J., Pelckmans, P. A. et al. (2013). Mechanisms of pelvic organ crosstalk: 1. Peripheral modulation of bladder inhibition by colorectal distention in rats. J. Urol. 190, 765-771. doi: 10.1016/j.juro.2013.03.045

$\mathrm{Xu}$, S., Cheng, Y., Keast, J. R., and Osborne, P. B. (2008). 17betaestradiol activates estrogen receptor beta-signalling and inhibits transient receptor potential vanilloid receptor 1 activation by capsaicin in adult rat nociceptor neurons. Endocrinology 149, 5540-5548. doi: 10.1210/en.20 08-0278

Yan, T., Liu, B., Du, D., Eisenach, J. C., and Tong, C. (2007). Estrogen amplifies pain responses to uterine cervical distension in rats by altering transient receptor potential-1 function. Anesth. Analg. 104, 1246-1250, tables of contents. doi: 10.1213/01.ane.0000263270.39480.a2

Yuce, B., Kemmer, M., Qian, G., Muller, M., Sibaev, A., Li, Y., et al. (2010). Cannabinoid 1 receptors modulate intestinal sensory and motor function in rat. Neurogastroenterol. Motil. 22, 672-e205. doi: 10.1111/j.1365-2982.2010.01473.x

Zagorodnyuk, V. P., Gibbins, I. L., Costa, M., Brookes, S. J., and Gregory, S. J. (2007). Properties of the major classes of mechanoreceptors in the guinea pig bladder. J. Physiol. 585, 147-163. doi: 10.1113/jphysiol.2007.140244

Zhu, Y., and Pintar, J. E. (1998). Expression of opioid receptors and ligands in pregnant mouse uterus and placenta. Biol. Reprod. 59, 925-932. doi: 10.1095/biolreprod59.4.925

Conflict of Interest Statement: The authors declare that the research was conducted in the absence of any commercial or financial relationships that could be construed as a potential conflict of interest.

Received: 14 December 2013; paper pending published: 16 January 2014; accepted: 27 January 2014; published online: 13 February 2014.

Citation: Jobling P, O'Hara K and Hua S (2014) Female reproductive tract pain: targets, challenges, and outcomes. Front. Pharmacol. 5:17. doi: 10.3389/fphar.2014.00017

This article was submitted to Neuropharmacology, a section of the journal Frontiers in Pharmacology.

Copyright (c) 2014 Jobling, O'Hara and Hua. This is an open-access article distributed under the terms of the Creative Commons Attribution License (CC BY). The use, distribution or reproduction in other forums is permitted, provided the original author(s) or licensor are credited and that the original publication in this journal is cited, in accordance with accepted academic practice. No use, distribution or reproduction is permitted which does not comply with these terms. 